\title{
Editorial: Crystal Archives of Magmatic Processes
}

\author{
Teresa Ubide ${ }^{1 *}$, David A. Neave ${ }^{2}$, Maurizio Petrelli ${ }^{3}$ and Marc-Antoine Longpré ${ }^{4,5}$ \\ ${ }^{1}$ School of Earth and Environmental Sciences, The University of Queensland, Brisbane, QLD, Australia, ${ }^{2}$ Department of Earth and \\ Environmental Sciences, The University of Manchester, Manchester, United Kingdom, ${ }^{3}$ Department of Physics and Geology, University of \\ Perugia, Perugia, Italy, ${ }^{4}$ School of Earth and Environmental Sciences, Queens College, City University of New York, Queens, NY, United \\ States, ${ }^{5}$ Earth and Environmental Sciences, The Graduate Center, City University of New York, New York, NY, United States
}

Keywords: crystal zoning, magma transport, magma storage, timescales, volcano plumbing system

Editorial on the Research Topic

Crystal Archives of Magmatic Processes

Crystals are direct witnesses of intricate journeys of magma transfer and storage through Earth's mantle and crust. Crystals thus provide windows into processes that are physically inaccessible yet control volcanic behaviour, ore mineralisation and crustal growth (Maclennan et al., 2001; Davidson et al., 2007; Streck, 2008; Cashman et al., 2017; Ubide and Kamber, 2018; Edmonds et al., 2019; Hepworth et al., 2020). However, unravelling crystal archives requires a detailed understanding of how magmatic information is both recorded during crystal growth and then preserved during subsequent storage and transport.

The sensitivity of crystal morphology and zonation to magmatic conditions varies between minerals, and their melt inclusions. High resolution geochemistry resolves ever increasing intracrystal complexities (Davidson et al., 2007; Oeser et al., 2015; Till et al., 2015; Ubide et al.,

\section{OPEN ACCESS}

Edited and reviewed by: Catherine Jeanne Annen, Institute of Geophysics (ASCR),

Czechia

${ }^{*}$ Correspondence: Teresa Ubide t.ubide@uq.edu.au

Specialty section: This article was submitted to

Petrology,

a section of the journal

Frontiers in Earth Science

Received: 29 July 2021 Accepted: 06 August 2021 Published: 20 August 2021

Citation:

Ubide T, Neave DA, Petrelli $M$ and Longpré M-A (2021) Editorial: Crystal Archives of Magmatic Processes. Front. Earth Sci. 9:749100. doi: 10.3389/feart.2021.749100
2015; Neave et al., 2017; Cao et al., 2019). Experimental observations help us link crystal textures and compositions with geological processes, and thereby reconstruct the structure and dynamics of magma storage regions in ways that can be eventually integrated with geophysical data (Hammer, 2008; Putirka 2008; Gualda et al., 2012; Neave and Putirka 2017; Mollo et al., 2018). The diffusive overprinting of chemical zoning may erase precious records and complicate the integration of plutonic and volcanic archives, but it also enables us to quantify timescales of magma storage and transport, informing volcano monitoring efforts (Kahl et al., 2011; Longpré et al., 2014; Petrone et al., 2016; Rasmussen et al., 2018; Mutch et al., 2019; Costa et al., 2020; Petrelli and Zellmer, 2020).

This Research Topic aims to bring new insights into our understanding of how crystal archives can be used to reconstruct the dynamics of magmatic systems. Thirteen original research articles exploit the crystal-eye to magmatic processes by applying novel petrological and geochemical approaches to a range of natural and experimental case studies that access different portions of magma plumbing systems (Figure 1). The articles in this Research Topic demonstrate how overcoming the challenges related to the study of crystal archives can open new opportunities for understanding otherwise cryptic magma pathways from source to eruption.

\section{MAKING CRYSTAL ARCHIVES}

As magmas crystallise, growing minerals respond to melt compositions and magmatic conditions via their textural characteristics, chemistry and style of compositional zoning (Figure 1A). Large crystals have traditionally been considered to grow in a tree-ring fashion, with concentric zones forming sequentially from core to rim, and compositional zoning reflecting sequential changes in the 


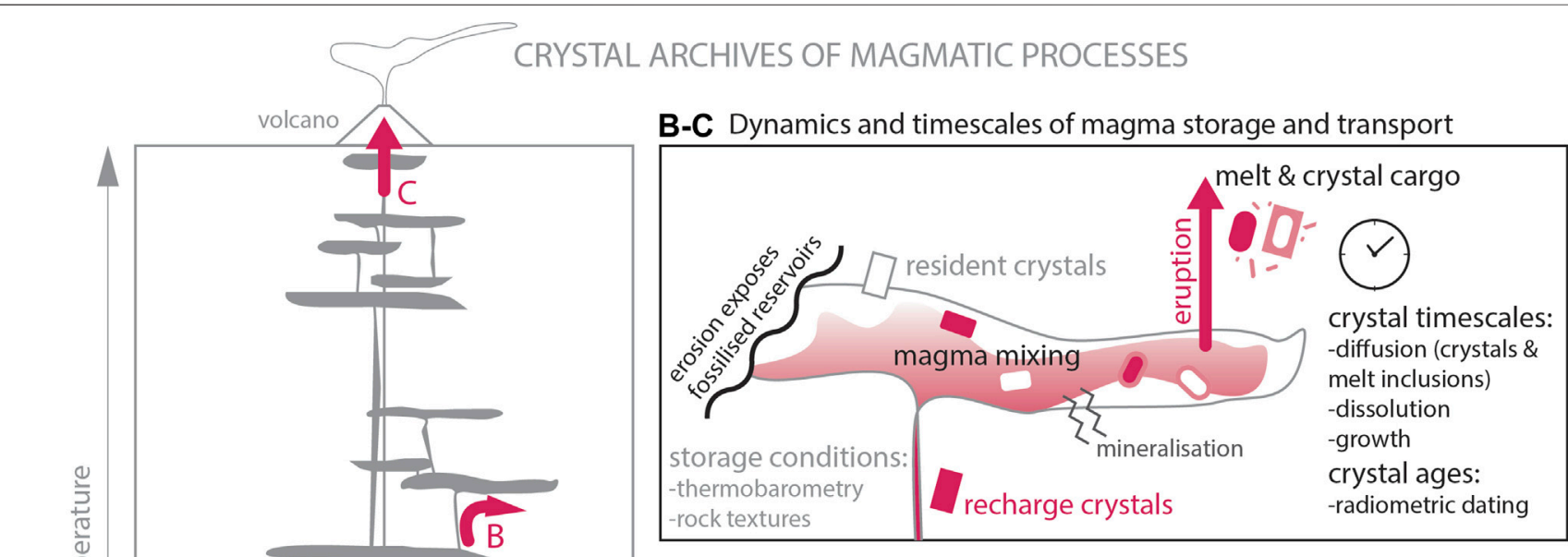

A Making crystal archives
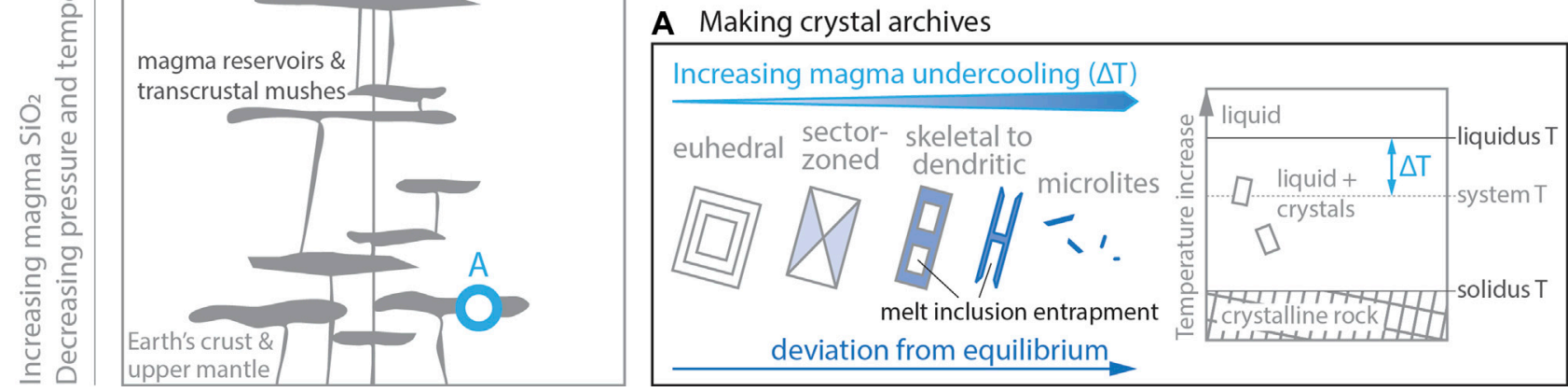

FIGURE 1 | The crystal-eye on magma plumbing systems. Crystal archives unveil the processes, depths and timescales of magma transport and storage from source to eruption. The present Research Topic explores frontiers in magmatic processes exploiting crystal and melt inclusion records. (A) Making crystal archives. Variations in crystal morphology, zoning style and entrapment of melt inclusions with the increase in magma undercooling. The degree of magma undercooling $(\Delta T)$ increases if the temperature of the system decreases (e.g., due to cooling at the reservoir margin) or if the liquidus temperature increases (e.g., due to degassing). (B) Crystals record the dynamics of magma storage and transport between reservoirs, including magma fractionation, recharge, mixing, assimilation, degassing and mush remobilisation. Erupted magmas carry an assortment of crystals (phenocrysts, antecrysts, xenocrysts) that attest to complex pre-eruptive histories. Fossilised magma chambers enable direct observation of crystal records of magmatic processes, and their potential link to mineralisation. (C) Crystals act as time capsules of reservoir growth and eruption onset. A variety of timescales can be retrieved applying constraints on the kinetics of crystal growth, dissolution and diffusive re-equilibration in minerals and their melt inclusions.

magmatic environment through time. However, rapid growth at moderate to high degrees of undercooling $\left(\Delta T=T_{\text {liquidus }}-\right.$ $T_{\text {crystallisation }}$ ) generates skeletal to dendritic crystals that grow in a snow-flake fashion with disequilibrium compositions, and can be later infilled via concentric growth, complicating crystal records (Faure et al., 2003; Welsch et al., 2014; Shea et al., 2015; Salas et al., 2021). At low degrees of undercooling, polyhedral crystals can develop sector zoning, where sectors growing coevally along different crystallographic directions have distinct compositions, further complicating crystal archives (Hollister and Gancarz, 1971; Kouchi et al., 1983; Ubide et al., 2019a; Masotta et al., 2020). Conversely, recognising kinetic effects can provide invaluable information about the thermal pathways of magma crystallisation (Bouvet de Maisonneuve et al., 2016; Welsch et al., 2016; Ubide et al., 2019a, Ubide et., 2019b; Neave et al., 2019; Shea et al., 2019; Di Stefano et al., 2020). In addition, diffusive re-equilibration of compositional gradients can generate or modify chemical profiles across crystals, and diffusion modelling can retrieve a wide range of timescales across magmatic plumbing systems (Costa et al., 2020).
To constrain the effects of undercooling and time on olivine growth and zoning, Mourey and Shea perform experiments on a Hawaiian tholeiite, and investigate resulting crystals with threedimensional X-ray micro-tomography. Estimated 3D growth rates $\left(10^{-7} \mathrm{~m} / \mathrm{s}\right)$ are almost an order of magnitude higher than those calculated using $2 \mathrm{D}$ sections of the same experiments, highlighting the benefit of their novel 3D approach. At $\Delta T=40^{\circ} \mathrm{C}$, growth rates approach their maxima while nucleation rates remain low, so this may represent a thermal "sweet spot" for the formation of large crystals in dry basalts. A magma chamber can thus generate large crystals within a few hours of thermal perturbations induced, for example, by magma mixing. Crystal growth is initially rapid, and the crystal skeleton forms at a faster pace than diffusion of both moderate $(\mathrm{Fe}-\mathrm{Mg}$ ) and fast (Li) diffusing elements, which complies with a necessary assumption for the application of diffusion chronometry (Costa et al., 2008; Costa et al., 2020). In contrast, subsequent maturation to large polyhedral crystals is comparatively slow, and gradual compositional changes are controlled by diffusive reequilibration. The initial, rapid formation of an outer crystal 
shell enhances the confinement of melt inclusions, which are common in olivine.

Melt inclusions trapped by growing crystals provide distinct records of magmatic evolution (Kent et al., 2010). An important assumption is that entrapped melts are representative of the bulk environment and not liquid boundary layers created during fast crystal growth (Baker, 2008; Longpré et al., 2020). Moreover, the effects of post-entrapment crystallisation within inclusions need to be carefully assessed, as well as the effects of experimentally reheating inclusions prior to microanalysis (Nielsen, 2011). In this context, Lewis et al. undertake an experimental study on the homogenisation of plagioclase-hosted melt inclusions, testing changes in the major and trace element chemistry of glass with pressure and duration of experiments. They find that the best approach for recovering compositions at the time of entrapment is to homogenise the inclusions for short times at low pressure (melt inclusions up to 500 microns in diameter homogenize in $30 \mathrm{~min}$ or less), or at the pressure of entrapment (calculated according to $\mathrm{CO}_{2}$ contents). The authors provide detailed recommendations to reverse post-entrapment processes and thereby reconstruct pre-eruptive magma evolution.

\section{DYNAMICS OF MAGMA STORAGE}

The complex nature of subvolcanic plumbing systems reflects magma evolution by a succession of dynamic processes involving magma fractionation, recharge, mixing, assimilation and degassing, which may occur in numerous reservoirs and during magma transfer through crystal mushes (Bergantz et al., 2015; Cashman et al., 2017; Edmonds et al., 2019). This translates into the occurrence of crystal populations with disparate origins at the scale of individual crystals, thin sections and outcrops (equilibrium phenocrysts/autocrysts, cogenetic antecrysts, accidental xenocrysts; Davidson et al., 2007; Kahl et al., 2015). Interrogating the crystal cargo erupted during volcanism or fossilised in intrusions provides a forensic means to access the inner workings of magmatic systems (Figure 1B).

To disentangle crystal populations and discern their origins, Caricchi et al. apply machine learning methods to clinopyroxenes erupted during the 2014-2015 Bárðarbunga-Holuhraun eruption in Iceland, where lateral draining of the magma reservoir induced progressive caldera collapse (Gudmundsson et al., 2016). Hierarchical clustering of clinopyroxene major and trace element datasets distinguishes hourglass and prism sectors, as well as concentrically zoned mantles and overgrowth rims, which together respond to thermal variations and associated kinetic effects. Results unveil a sequence of pre-eruptive processes that had not been captured in previous whole rock and melt inclusion studies, including mixing of hot magma with colder resident magma during lateral transport across the feeder dyke. Variations in crystal populations throughout the 6 months of the eruption indicate a decrease in magma mixing with time, which the authors suggest could be linked to the thermal maturation of the dyke. Combined with monitoring data, statistical assessments of crystal zoning provide powerful means to track pre- and syneruptive pathways of magma movement towards the surface.

Locating pockets of magma storage prior to eruption is critical in the surveillance of volcanoes across tectonic settings. Klügel et al. investigate crystal and melt records in a chronologicallycontrolled sample sequence of the 2014-15 eruption at Fogo, Cape Verde, as a natural laboratory to reconstruct magma plumbing in an ocean island setting. Clinopyroxene-melt barometry on carefully filtered equilibrium pairs of rims and groundmass indicates magma storage at upper mantle levels. Clinopyroxene rims are sector-zoned and formed during the eruption, due to $\mathrm{H}_{2} \mathrm{O}$-loss that might have been driven by $\mathrm{CO}_{2}$-flushing from deeper reservoirs. Microthermometry of $\mathrm{CO}_{2}$-dominated fluid inclusions in clinopyroxene indicates the ascending magma stalled briefly at the Moho, and diffusion modelling of olivine rims indicates final ascent was fast (on the order of hours). In contrast with other documented eruptions of ocean island basalts, the majority of seismic events precursory to the Fogo eruption were relatively shallow compared to the depths of magma stagnation indicated by barometry. The authors suggest this might be due to short recurrence intervals and small erupted volumes resulting in mostly aseismic magma ascent, which could help inform the monitoring of future volcanic activity at Fogo.

In alkaline continental systems, explosive monogenetic centers can erupt unusual cargoes of crystals and lithics (Irving and Frey, 1984), which may provide valuable constraints on magma source, ascent and eruption. In addition, the unpredictability and abundance of monogenetic volcanoes underline the importance of improving our understanding of their source to surface feeding mechanisms (Smith and Németh, 2017; Brenna et al., 2021). Villaseca et al. investigate spectacular megacryst and cumulate cargoes in the Cenozoic Calatrava volcanic field in central Spain. Trace element signatures in clinopyroxene, amphibole and phlogopite, combined with $\mathrm{Sr}-\mathrm{Nd}$ isotope systematics in minerals and whole rocks, indicate the disparate cargoes share a common origin. Green Fe-Na-rich clinopyroxenes are interpreted as high-pressure precipitates from highly fractionated liquids, cogenetic with the less fractionated melts that formed colourless clinopyroxenes. Crucially, trace element data serve to test the origin of green clinopyroxenes as cognate vs. xenocrystic cargo, as highlighted in other alkaline settings (Ubide et al., 2014; Jankovics et al., 2016). Results support the notion that alkaline monogenetic fields are fed by deep magmatic systems governed by melt accumulation, fractionation and contamination at variable mantle depths, and in which volatile saturation ultimately triggers mush disaggregation and rapid magma ascent.

Shallow crustal storage is often well developed above deep mafic mushes in arc settings (Annen et al., 2006). Nicotra et al. link plagioclase records with eruptive styles across the volcano stratigraphy of small caldera-forming eruptions at Vulcano (Aeolian Islands, Italy). The authors propose the re-activation of caldera ring-faults may induce decompression of shoshonitic magma and its crystal cargo stored at shallow depths, as well as basaltic, volatile-rich magma with more primitive crystals stored below the level of water exsolution. Decompression of plagioclase 
from the shallow reservoir creates sieve textures rich in melt inclusions, overgrowing finely oscillatory zoned cores formed under quiescent conditions. Ascending primitive magma carries resorbed plagioclases, and mixing between recharge and resident magmas results in further resorption. Interestingly, the establishment of magma mixing in the shallow reservoir may follow the transition from phreatomagmatic explosions at the onset of volcanism to sustained lava fountaining, whereby progressive tapping of primitive basalts leads to a shift in eruptive style from Strombolian to Hawaiian. Ring-faults and fractures play a crucial role in channelising rapid magma ascent, leading to partial reservoir emptying and caldera collapse.

Knafelc et al. show that even crystal-poor rhyolites may carry mixed crystal cargoes. In a multi-mineral investigation of the Havre 2012 large submarine eruption in the southwest Pacific, including pumice raft collected along the east coast of Australia and Fiji, as well as samples of seafloor giant pumice and lava flows from the eruption site, the authors show that the mineral assemblage comprises both equilibrium autocrysts and recycled antecrysts. Importantly, they focus only on the autocrysts (plagioclase, orthopyroxene and Fe-Ti oxides) to constrain the pressure, temperature, water content and oxidation state of carrier melts immediately before eruption. Thermodynamic modelling indicates that clinopyroxene and quartz antecrysts are inherited from cold, silicic mush zones. Resorbed high-An plagioclase cores may be sourced from more mafic-intermediate magma. The study highlights the need of careful textural and compositional assessment of mineral-melt equilibrium to reconstruct pre-eruptive processes and architecture across magma compositions and eruptive styles.

\section{Plutonic Perspectives}

While mineral assemblages in volcanic rocks preserve complex zoning records due to fast cooling upon eruption, they represent only a portion of crystals processed within magmatic plumbing systems. Plutonic complexes provide direct access to fossilised plumbing systems and the processes occurring during magma solidification that are not necessarily reflected in volcanic records. Holness et al. quantify plagioclase shapes and fabrics in oriented thin sections of troctolitic cumulate bodies from the Layered Series of the Skaergaard intrusion, and the Rum Eastern Layered Intrusion, to assess crystal mobilization, transport and accumulation. Plagioclase foliation becomes stronger as grains become more tabular with increasing cooling rates and corresponding crystal growth rates. The authors link foliations to magmatic currents, tectonic disruptions of poorly consolidated mush, or post-accumulation overgrowths. Upward increases in foliation strength provide detailed records of progressive magma chamber inflation. In turn, frequent replenishment events favour textural equilibration during slow sub-solidus cooling, modifying igneous microstructures. The authors observe a correlation between the standard deviation of dihedral angles at plagioclase triple junctions and the average grain shape, and suggest future research should explore such variation as a means to quantify cumulate thermal histories.
Olivine- and pyroxene-rich cumulates can host $\mathrm{Ni}-\mathrm{Cu}-$ (platinum group element-PGE) sulphide deposits. Schoneveld et al. explore the potential of pyroxene zoning to record the processes that lead to mineralisation. The authors examine mineralised and barren intrusions across the globe via X-ray fluorescence imaging, which reveals crystal zoning patterns across entire thin sections. Pyroxene zoning is particularly well preserved for slow-diffusing $\mathrm{Cr}$, enhanced in compositional maps obtained at low energy of synchrotron X-rays (Barnes et al., 2020). Interestingly, pyroxene zoning is widespread across mafic intrusions and the zonation styles vary between mineralised and barren bodies. Strongly mineralized intrusions contain pyroxenes with complex $\mathrm{Cr}$ variations, including abrupt and sector zoning in orthopyroxenes that contain olivine inclusions. The authors interpret these features as reactive transport of olivine and orthopyroxene crystals within high-flux, dynamic conduit systems where wall rock assimilation induces fluctuations in magmatic conditions and leads to $\mathrm{Ni}-\mathrm{Cu}$ sulphide mineralization (Barnes et al., 2016). This study grows an exciting line of research on the potential of zoned crystals as fertility indicators for the exploration of ore deposits.

\section{TIMESCALES OF MAGMA ASCENT TO ERUPTION}

Crystals act as chronometers that enable the reconstruction of magma transport and storage through time (Cooper and Kent, 2014; Costa et al., 2020; Figure 1C). Olivine is extensively exploited for diffusion chronometry in basaltic systems, partly because slow- (e.g., P), moderate- (e.g., Fe-Mg) and fast- (e.g., Li) diffusing elements resolve a wide range of magmatic timescales (Lynn et al., 2018; Costa et al., 2020). Increasing interest in syneruptive processes such as magma ascent and degassing has promoted studies focused on fast-diffusing Li. However, charge balancing the incorporation of pentavalent $\mathrm{P}$ by monovalent $\mathrm{Li}$ during rapid olivine growth (Mallmann et al., 2009) calls for careful assessment of the origin of Li concentration gradients.

To untangle Li records of growth and diffusion, Lynn et al. target trace element zoning in carefully oriented and sectioned olivines from Hawaii, using a combination of electron microprobe, laser ablation mass spectrometry and nanoscale secondary ion mass spectrometry. Li variations can be grouped into two types: 1) broad core-rim zoning that is not coupled with $\mathrm{P}$; 2) fine Li enrichments that are coupled with $\mathrm{P}$ and only resolved quantitatively via sub-micrometre analysis. The authors link the non-coupled $\mathrm{Li}$ variations to diffusion after magma mixing, which can be modelled to retrieve short timescales (hours to days) of magma intrusion and transport to eruption. In contrast, coupled $\mathrm{Li}$ enrichments reflect early rapid growth along branches rich in $\mathrm{P}$ and cannot be reliably modelled due to complications arising from multi-component diffusion, poorly constrained initial conditions and analytical challenges associated with resolving fine variations. The authors conclude that only broad zoning of non-coupled $\mathrm{Li}$ should be modelled for timescales of magmatic processes, and 
provide detailed recommendations on selecting $\mathrm{Li}$ profiles for diffusion modelling.

Steinnmann et al. approach the issue of crystal growth vs. diffusion by combining Li elemental and isotope zoning in olivines from the Massif Central in France. The authors measure $\mathrm{Li}$ isotope variations via femtosecond laser ablation multi-collector mass spectrometry, previously used to obtain $\mathrm{Fe}-\mathrm{Mg}$ isotope profiles across the same olivines (Oeser et al., 2015). The isotopic composition of the melt is assumed to be constant during fractional crystallisation, and significant increases in both $\mathrm{Li}$ and $\delta^{7} \mathrm{Li}$ from olivine cores to rims are interpreted as resulting from diffusion into initially homogeneous olivine grains during magma differentiation. Such zoning broadly correlates with $\mathrm{Fe}-\mathrm{Mg}$ variations, which are used to retrieve timescale information. In addition, Li shoulders at crystal rims reveal a second diffusion event ( $\mathrm{Li}$ loss) that is not recorded by $\mathrm{Mg}-\mathrm{Fe}$ exchange and may reflect degassing during magma ascent or eruption. Importantly, integrated elemental and isotope profiles of $\mathrm{Fe}-\mathrm{Mg}$ and $\mathrm{Li}$ resolve the origin of olivine compositional variations and help unravel multi-stage magma evolution, including cooling, magma mixing and degassing.

The thermal history of magmas during final ascent is crucial to investigate the explosivity of eruptions and help interpret volcano degassing records (La Spina et al., 2015; Oppenheimer et al., 2018). Newcombe et al. explore magma pressure-temperaturetime (P-T-t) paths immediately before basaltic eruptions from arc and ocean island volcanoes of different explosivity and magma water content. They combine thermal histories (T- $t$ ) from $\mathrm{MgO}$ diffusion profiles in olivine-hosted melt inclusions with decompression histories (P-t) previously determined from volatile data. Results indicate a negative correlation between syn-eruptive magma decompression rates and cooling rates; rapidly ascending gas-bearing magmas (subplinian volcanism) experience slower cooling during ascent and eruption than slowly ascending magmas (lava-fountaining). Thermal histories of hydrous arc magmas are not accurately modelled by isentropic magma ascent, where adiabatic expansion of the gas phase is the dominant driver of cooling in the conduit. This may be due to open-system degassing and/or degassing-driven crystallisation, which produces latent heat (Blundy et al., 2006), and argues against the use of isentropic conduit models for arc magmas. The proposed syn-eruptive ascent thermo-chronometer offers a new approach for constraining conduit processes, including magma stalling, magma mixing, open- and closed-system degassing, vapour fluxing, and vapour accumulation during the seconds to hours preceding mafic eruptions.

Water-poor magmas in mid ocean ridge settings pose a challenge for decompression rates based on degassing records. Neave and Maclennan combine experimental constraints on clinopyroxene dissolution with barometric estimates to calculate decompression rates from a wehrlite nodule from the primitive Borgarhraun lava flow in Iceland. Crystal cores have Alrich compositions consistent with crystallisation at Moho levels. Crystal rims and inclusions have $\mathrm{Al}$-poor compositions that formed at or near the surface. Crucially, rims and inclusions are interpreted as the crystallised remnants of boundary layers formed by the dissolution of high-Al cores during magma ascent, providing a means to calculate ascent timescales. The model returns mantle-to-surface transport durations on the order of days, implying limited unrest may precede some Icelandic eruptions. Results are faster than previous estimates based on olivine diffusion chronometry (Mutch et al., 2019), suggesting that magmas accelerate close to the surface. Interestingly, results are similar to those obtained in arc settings, indicating that magma ascent rates may not correlate simply with magma water contents (Cassidy et al., 2018). The proposed decompression-meter provides a way to estimate decompression rates of water-poor magmas, and highlights the benefits of integrating timescale information from different geospeedometers.

\section{SUMMARY AND FUTURE OUTLOOK}

Crystals can help locate regions of magma storage at depth, identify the processes that govern magma ascent and provide time constraints on the triggers of volcanic eruptions. Outstanding challenges include a precise understanding on the complex and overlapping magmatic processes and timescales different minerals are able to record, and preserve, and a careful assessment of the applicability of petrological calibrations established in experimental conditions to natural systems where equilibrium conditions rarely apply. Fortunately, these difficulties are increasingly overcome by exciting developments in experimental, analytical and numerical approaches that bring new perspectives to crystal archives, as highlighted by this Research Topic.

Crystal textures can now be quantified with greater precision and accuracy than ever before. While advanced methods such as the non-destructive 3D X-ray microtomography used by Mourey and Shea are providing previously unattainable insights into rock microstructures, Holness et al. demonstrate that optical microscopy still has a central role to play in advancing our understanding of magma reservoir processes. Technological advances like those exploited by Neave and Maclennan and Schoneveld et al. now make it possible to map compositional variations over whole thin sections, explicitly integrating textural and chemical information and highlighting previously missed features, even in comprehensively studied samples. Future challenges are likely to involve rethinking how the enormous volumes of data generated by such approaches can be presented in transparent yet digestible ways. Although high-precision geochemical microanalyses like the fs-LA-MC-ICP-MS used by Steinmann et al. and the nanoSIMS used by Lynn et al. and Newcombe et al. are now well established tools for reconstructing magmatic histories from crystal zoning, applications to geological systems are still relatively few in number, and many new discoveries can be expected in the years ahead as these techniques mature further. Finally, the ever larger datasets now generated are fueling the growth of quantitative petrology, and statistical approaches like that presented by Caricchi et al. offer exciting new opportunities for better understanding crystal archives of magmatic processes. 


\section{AUTHOR CONTRIBUTIONS}

TU drafted the first version of the text and figure, with input from DAN. All authors contributed to the final version of the article.

\section{FUNDING}

TU was supported by a Foundation Research Excellence Award from The University of Queensland (UQ-FREA RM2019001828), the Advance Queensland Women's Research Assistance Program from the Queensland Government (WRAP109-2019RD1 and RM2020002371), and the Australian Research Council (DP190100814 and DP200101566). DAN was supported by a Presidential Fellowship from the University of Manchester and a NERC

\section{REFERENCES}

Annen, C., Blundy, J. D., and Sparks, R. S. J. (2006). The Genesis of Intermediate and Silicic Magmas in Deep Crustal Hot Zones. J. Petrol. 47, 505-539. doi:10.1093/petrology/egi084

Baker, D. R. (2008). The Fidelity of Melt Inclusions as Records of Melt Composition. Contrib. Mineral. Petrol. 156, 377-395. doi:10.1007/s00410008-0291-3

Barnes, S. J., Mole, D. R., Le Vaillant, M., Campbell, M. J., Verrall, M. R., Roberts, M. P., et al. (2016). Poikilitic Textures, Heteradcumulates and Zoned Orthopyroxenes in the Ntaka Ultramafic Complex, Tanzania: Implications for Crystallization Mechanisms of Oikocrysts. J. Petrol. 57, 1171-1198. doi:10.1093/petrology/egw036

Barnes, S. J., Paterson, D., Ubide, T., Schoneveld, L. E., Ryan, C., and Le Vaillant, M. (2020). Imaging Trace-Element Zoning in Pyroxenes Using Synchrotron XRF Mapping with the Maia Detector Array: Benefit of Low-Incident Energy. Am. Mineral. 105, 136-140. doi:10.2138/am-2020-7228

Bergantz, G. W., Schleicher, J. M., and Burgisser, A. (2015). Open-system Dynamics and Mixing in Magma Mushes. Nat. Geosci. 8, 793-796. doi:10.1038/ngeo2534

Blundy, J., Cashman, K., and Humphreys, M. (2006). Magma Heating by Decompression-Driven Crystallization beneath Andesite Volcanoes. Nature 443, 76-80. doi:10.1038/nature05100

Brenna, M., Ubide, T., Nichols, A. R. L., Mollo, S., and Pontesilli, A. (2021). "Anatomy of Intraplate Monogenetic Alkaline Basaltic Magmatism," in Crustal Magmatic System Evolution: Anatomy, Architecture, and Physico-Chemical Processes. AGU Geophysical Monograph. Editors M. Masotta, C. Beier, and S. Mollo, 264, 79-103. doi:10.1002/9781119564485.ch4

Cao, M., Evans, N. J., Reddy, S. M., Fougerouse, D., Hollings, P., Saxey, D. W., et al. (2019). Micro- and Nano-Scale Textural and Compositional Zonation in Plagioclase at the Black Mountain Porphyry $\mathrm{Cu}$ deposit: Implications for Magmatic Processes. Am. Mineral. 104, 391-402. doi:10.2138/am-2019-6609

Cashman, K. V., Sparks, R. S. J., and Blundy, J. D. (2017). Vertically Extensive and Unstable Magmatic Systems: a Unified View of Igneous Processes. Science 355, eaag3055. doi:10.1126/science.aag3055

Cassidy, M., Manga, M., Cashman, K., and Bachmann, O. (2018). Controls on Explosive-Effusive Volcanic Eruption Styles. Nat. Commun. 9, 2839. doi:10.1038/s41467-018-05293-3

Cooper, K. M., and Kent, A. J. R. (2014). Rapid Remobilization of Magmatic Crystals Kept in Cold Storage. Nature 506, 480-483. doi:10.1038/nature12991

Costa, F., Dohmen, R., and Chakraborty, S. (2008). Time Scales of Magmatic Processes from Modeling the Zoning Patterns of Crystals. Rev. Mineral. Geochem. 69, 545-594. doi:10.2138/rmg.2008.69.14

Costa, F., Shea, T., and Ubide, T. (2020). Diffusion Chronometry and the Timescales of Magmatic Processes. Nat. Rev. Earth Environ. 1, 201-214. doi:10.1038/s43017-020-0038-x
Independent Research Fellowship (NE/T011106/1). MP acknowledges the Engage FRB2019 project by Perugia University. MAL acknowledges support from NSF awards \# 1650379, 1819053 and 1944723, and the Paula and Jeffrey Gural Endowed Professorship in Geology at Queens College.

\section{ACKNOWLEDGMENTS}

We thank all contributing authors, reviewers and additional editors for sharing their science, insights and time, making this Research Topic an exciting collection that reflects current understanding and novel approaches to the study of crystal archives. We thank Camilla Imarisio, Ursula Rabar and Roshan Patel from the Frontiers in Earth Science team for the invitation to submit the Research Topic proposal, and the support through the editorial process.

Davidson, J. P., Morgan, D. J., Charlier, B. L. A., Harlou, R., and Hora, J. M. (2007) Microsampling and Isotopic Analysis of Igneous Rocks: Implications for the Study of Magmatic Systems. Annu. Rev. Earth Planet. Sci. 35, 273-311. doi:10.1146/annurev.earth.35.031306.140211

de Maisonneuve, C. B., Costa, F., Huber, C., Vonlanthen, P., Bachmann, O., and Dungan, M. A. (2016). How Do Olivines Record Magmatic Events? Insights from Major and Trace Element Zoning. Contrib. Mineral. Petrol. 171, 56. doi:10.1007/s00410-016-1264-6

Di Stefano, F., Mollo, S., Ubide, T., Petrone, C. M., Caulfield, J., Scarlato, P., et al (2020). Mush Cannibalism and Disruption Recorded by Clinopyroxene Phenocrysts at Stromboli Volcano: New Insights from Recent 2003-2017 Activity. Lithos 360-361, 105440. doi:10.1016/j.lithos.2020.105440

Edmonds, M., Cashman, K. V., Holness, M., and Jackson, M. (2019). Architecture and Dynamics of Magma Reservoirs. Phil. Trans. R. Soc. A. 377, 20180298 doi:10.1098/rsta.2018.0298

Faure, F., Trolliard, G., Nicollet, C., and Montel, J. M. (2003). A Developmental Model of Olivine Morphology as a Function of the Cooling Rate and the Degree of Undercooling. Contrib. Mineral. Petrol. 145, 251-263. doi:10.1007/s00410003-0449-y

Gualda, G. A. R., Ghiorso, M. S., Lemons, R. V., and Carley, T. L. (2012). RhyoliteMELTS: a Modified Calibration of MELTS Optimized for Silica-Rich, FluidBearing Magmatic Systems. J. Petrol. 53, 875-890. doi:10.1093/petrology/ egr080

Gudmundsson, M. T., Jónsdóttir, K., Hooper, A., Holohan, E. P., Halldórsson, S. A., Ófeigsson, B. G., et al. (2016). Gradual Caldera Collapse at Bárdarbunga Volcano, Iceland, Regulated by Lateral Magma Outflow. Science 353, aaf8988. doi:10.1126/science.aaf8988

Hammer, J. E. (2008). Experimental Studies of the Kinetics and Energetics of Magma Crystallization. Rev. Mineralogy Geochem. 69 (1), 9-59. doi:10.2138/ rmg.2008.69.2

Hepworth, L. N., Daly, J. S., Gertisser, R., Johnson, C. G., Emeleus, C. H., and O'Driscoll, B. (2020). Rapid Crystallization of Precious-Metal-Mineralized Layers in Mafic Magmatic Systems. Nat. Geosci. 13, 375-381. doi:10.1038/ s41561-020-0568-3

Hollister, L. S., and Gancarz, A. J. (1971). Compositional Sector-Zoning in Clinopyroxene from the Narce Area. Italy. Am. Mineral. 56, 959.

Irving, A. J., and Frey, F. A. (1984). Trace Element Abundances in Megacrysts and Their Host Basalts: Constraints on Partition Coefficients and Megacryst Genesis. Geochim. Cosmochim. Acta 48, 1201-1221. doi:10.1016/00167037(84)90056-5

Jankovics, M. É., Taracsák, Z., Dobosi, G., Embey-Isztin, A., Batki, A., Harangi, S., et al. (2016). Clinopyroxene with Diverse Origins in Alkaline Basalts from the Western Pannonian Basin: Implications from Trace Element Characteristics. Lithos 262, 120-134. doi:10.1016/j.lithos.2016.06.030

Kahl, M., Chakraborty, S., Costa, F., and Pompilio, M. (2011). Dynamic Plumbing System beneath Volcanoes Revealed by Kinetic Modeling, and the Connection 
to Monitoring Data: an Example from Mt. Etna. Earth Planet. Sci. Lett. 308 (1-2), 11-22. doi:10.1016/j.epsl.2011.05.008

Kahl, M., Chakraborty, S., Pompilio, M., and Costa, F. (2015). Constraints on the Nature and Evolution of the Magma Plumbing System of Mt. Etna Volcano (1991-2008) from a Combined Thermodynamic and Kinetic Modelling of the Compositional Record of Minerals. J. Petrol. 56, 2025-2068. doi:10.1093/petrology/egv063

Kent, A. J. R., Darr, C., Koleszar, A. M., Salisbury, M. J., and Cooper, K. M. (2010). Preferential Eruption of Andesitic Magmas through Recharge Filtering. Nat. Geosci. 3, 631-636. doi:10.1038/ngeo924

Kouchi, A., Sugawara, Y., Kashima, K., and Sunagawa, I. (1983). Laboratory Growth of Sector Zoned Clinopyroxenes in the System CaMgSi2O6CaTiAl2O6. Contr. Mineral. Petrol. 83, 177-184. doi:10.1007/BF00373091

La Spina, G., Burton, M., de' Michieli Vitturi, M., and Vitturi, M. (2015). Temperature Evolution during Magma Ascent in Basaltic Effusive Eruptions: a Numerical Application to Stromboli Volcano. Earth Planet. Sci. Lett. 426, 89-100. doi:10.1016/j.epsl.2015.06.015

Longpré, M.-A., Klügel, A., Diehl, A., and Stix, J. (2014). Mixing in Mantle Magma Reservoirs Prior to and during the 2011-2012 Eruption at El Hierro, Canary Islands. Geology 42 (4), 315-318. doi:10.1130/G35165.1

Longpré, M. A., Stix, J., and Shimizu, N. (2020). "Boundary-Layer Melts Entrapped as Melt Inclusions? The Case of Phosphorus- and $\mathrm{CO}_{2}$-Rich Spinel-Hosted Melt Inclusions from El Hierro, Canary Islands," in Dynamic Magma Evolution, Geophysical Monograph Series. Editor F. Vetere (Hoboken, NJ: AGU), 254, 43-60. doi:10.1002/9781119521143.ch2

Lynn, K. J., Shea, T., Garcia, M. O., Costa, F., and Norman, M. D. (2018). Lithium Diffusion in Olivine Records Magmatic Priming of Explosive Basaltic Eruptions. Earth Planet. Sci. Lett. 500, 127-135. doi:10.1016/j.epsl.2018.08.002

Maclennan, J., McKenzie, D., Gronvöld, K., and Slater, L. (2001). Crustal Accretion under Northern Iceland. Earth Planet. Sci. Lett. 191, 295-310. doi:10.1016/ S0012-821X(01)00420-4

Mallmann, G., O'Neill, H. S. C., and Klemme, S. (2009). Heterogeneous Distribution of Phosphorus in Olivine from Otherwise Well-Equilibrated Spinel Peridotite Xenoliths and its Implications for the Mantle Geochemistry of Lithium. Contrib. Mineral. Petrol. 158, 485-504. doi:10.1007/s00410-009-0393-6

Masotta, M., Pontesilli, A., Mollo, S., Armienti, P., Ubide, T., Nazzari, M., et al. (2020). The Role of Undercooling during Clinopyroxene Growth in Trachybasaltic Magmas: Insights on Magma Decompression and Cooling at Mt. Etna Volcano. Geochim. Cosmochim. Acta 268, 258-276. doi:10.1016/j.gca.2019.10.009

Mollo, S., Blundy, J., Scarlato, P., De Cristofaro, S. P., Tecchiato, V., Di Stefano, F., et al. (2018). An Integrated P-T-H2o-Lattice Strain Model to Quantify the Role of Clinopyroxene Fractionation on REE+Y and HFSE Patterns of Mafic Alkaline Magmas: Application to Eruptions at Mt. Etna. Earth-Science Rev. 185, 32-56. doi:10.1016/j.earscirev.2018.05.014

Mutch, E. J. F., Maclennan, J., Shorttle, O., Edmonds, M., and Rudge, J. F. (2019). Rapid Transcrustal Magma Movement under Iceland. Nat. Geosci. 12, 569-574. doi:10.1038/s41561-019-0376-9

Neave, D. A., and Putirka, K. D. (2017). A New Clinopyroxene-Liquid Barometer, and Implications for Magma Storage Pressures under Icelandic Rift Zones. Am. Mineral. 102, 777-794. doi:10.2138/am-2017-5968

Neave, D. A., Buisman, I., and Maclennan, J. (2017). Continuous Mush Disaggregation during the Long-Lasting Laki Fissure Eruption, Iceland. Am. Mineral. 102, 2007-2021. doi:10.2138/am-2017-6015CCBY

Neave, D. A., Bali, E., Guðfinnsson, G. H., Halldórsson, S. A., Kahl, M., Schmidt, A.-S., et al. (2019). Clinopyroxene-Liquid Equilibria and Geothermobarometry in Natural and Experimental Tholeiites: the 2014-2015 Holuhraun Eruption, Iceland. J. Petrol. 60, 1653-1680. doi:10.1093/petrology/egz042

Nielsen, R. L. (2011). The Effects of Re-homogenization on Plagioclase Hosted Melt Inclusions. Geochem. Geophys. Geosyst. 12, a-n. doi:10.1029/2011GC003822

Oeser, M., Dohmen, R., Horn, I., Schuth, S., and Weyer, S. (2015). Processes and Time Scales of Magmatic Evolution as Revealed by Fe-Mg Chemical and Isotopic Zoning in Natural Olivines. Geochim. Cosmochim. Acta 154, 130-150. doi:10.1016/j.gca.2015.01.025

Oppenheimer, C., Scaillet, B., Woods, A., Sutton, A. J., Elias, T., and Moussallam, Y. (2018). Influence of Eruptive Style on Volcanic Gas Emission Chemistry and Temperature. Nat. Geosci 11, 678-681. doi:10.1038/s41561-018-0194-5

Petrelli, M., Zellmer, G. F., and Vetere, F. (2020). "Rates and Timescales of Magma Transfer, Storage, Emplacement, and Eruption," in Dynamic Magma Evolution. Geophysical Monograph Series, 1-41. doi:10.1002/9781119521143.ch1
Petrone, C. M., Bugatti, G., Braschi, E., and Tommasini, S. (2016). Pre-eruptive Magmatic Processes Re-timed Using a Non-isothermal Approach to Magma Chamber Dynamics. Nat. Commun. 7, 12946. doi:10.1038/ncomms12946

Putirka, K. D. (2008). 3. Thermometers and Barometers for Volcanic Systems. Rev. Mineral. Geochem. 69, 61-120. doi:10.1515/9781501508486-004

Rasmussen, D. J., Plank, T. A., Roman, D. C., Power, J. A., Bodnar, R. J., and Hauri, E. H. (2018). When Does Eruption Run-Up Begin? Multidisciplinary Insight from the 1999 Eruption of Shishaldin Volcano. Earth Planet. Sci. Lett. 486, 1-14. doi:10.1016/j.epsl.2018.01.001

Salas, P., Ruprecht, P., and Hernández, L. (2021). Out-of-Sequence Skeletal Growth Causing Oscillatory Zoning in arc Olivines. Nat. Commun. 12, 4069. doi:10.1038/s41467-021-24275-6

Shea, T., Lynn, K. J., and Garcia, M. O. (2015). Cracking the Olivine Zoning Code: Distinguishing between crystal Growth and Diffusion. Geology 43, 935-938. doi:10.1130/G37082.1

Shea, T., Hammer, J. E., Hellebrand, E., Mourey, A. J., Costa, F., First, E. C., , et al. Lynn, K. J., Melnik, O. (2019). Phosphorus and aluminum zoning in Oolivine: contrasting behavior of two nominally incompatible trace elements. Contrib. Mineral. doi:10.1007/s00410-019-1618-710.1007/s00410-019-1618-y

Smith, I. E. M., and Németh, K. (2017). "Source to Surface Model of Monogenetic Volcanism: a Critical Review," in Monogenetic Volcanism. Editors K. Németh, G. Carrasco-Nuñez, J. J. Aranda-Gómez, and I. E. M. Smith (London, UK: Geological Society of London Special Publication), 446, 1-28. doi:10.1144/ sp446.14

Streck, M. J. (2008). Mineral Textures and Zoning as Evidence for Open System Processes. Rev. Mineral. Geochem. 69, 595-622. doi:10.2138/rmg.2008.69.15

Till, C. B., Vazquez, J. A., and Boyce, J. W. (2015). Months between Rejuvenation and Volcanic Eruption at Yellowstone Caldera, Wyoming. Geology 43, 695-698. doi:10.1130/g36862.1

Ubide, T., and Kamber, B. S. (2018). Volcanic Crystals as Time Capsules of Eruption History. Nat. Commun. 9 (1), 326. doi:10.1038/s41467-017-02274-w

Ubide, T., Gale, C., Larrea, P., Arranz, E., and Lago, M. (2014). Antecrysts and Their Effect on Rock Compositions: the Cretaceous Lamprophyre Suite in the Catalonian Coastal Ranges (NE Spain). Lithos 206- 207, 214-233.

Ubide, T., McKenna, C. A., Chew, D. M., and Kamber, B. S. (2015). High-resolution LA-ICP-MS Trace Element Mapping of Igneous Minerals: In Search of Magma Histories. Chem. Geol. 409, 157-168. doi:10.1016/j.chemgeo.2015.05.020

Ubide, T., Mollo, S., Zhao, J. X., Nazzari, M., and Scarlato, P. (2019a). Sector-zoned Clinopyroxene as a Recorder of Magma History, Eruption Triggers, and Ascent Rates. Geochim. Cosmochim. Acta 251, 265-283. doi:10.1016/j.gca.2019.02.021

Ubide, T., Caulfield, J., Brandt, C., Bussweiler, Y., Mollo, S., Di Stefano, F., et al. (2019b). Deep Magma Storage Revealed by Multi-Method Elemental Mapping of Clinopyroxene Megacrysts at Stromboli Volcano. Front. Earth Sci. 7, 239. doi:10.3389/feart.2019.00239

Welsch, B., Hammer, J., and Hellebrand, E. (2014). Phosphorus Zoning Reveals Dendritic Architecture of Olivine. Geology 42, 867-870. doi:10.1130/G35691.1

Welsch, B., Hammer, J., Baronnet, A., Jacob, S., Hellebrand, E., and Sinton, J. (2016). Clinopyroxene in Postshield Haleakala Ankaramite: 2. Texture, Compositional Zoning and Supersaturation in the Magma. Contrib. Mineral. Petrol. 171, 6. https://doi.org/10.1007/s00410-015-1213-9.

Conflict of Interest: The authors declare that the research was conducted in the absence of any commercial or financial relationships that could be construed as a potential conflict of interest.

Publisher's Note: All claims expressed in this article are solely those of the authors and do not necessarily represent those of their affiliated organizations, or those of the publisher, the editors and the reviewers. Any product that may be evaluated in this article, or claim that may be made by its manufacturer, is not guaranteed or endorsed by the publisher.

Copyright $\odot 2021$ Ubide, Neave, Petrelli and Longpré. This is an open-access article distributed under the terms of the Creative Commons Attribution License (CC BY). The use, distribution or reproduction in other forums is permitted, provided the original author(s) and the copyright owner(s) are credited and that the original publication in this journal is cited, in accordance with accepted academic practice. No use, distribution or reproduction is permitted which does not comply with these terms. 